\title{
EVALUATION OF THE EFFECT OF PIPER BETLE L. LEAVES EXTRACT AGAINST CLONIDINE-INDUCED CATALEPSY AND MILK-INDUCED LEUKOCYTOSIS AND EOSINOPHILIA IN MICE
}

\author{
RAMDAS N KALE ${ }^{1 *}$, RAVINDRA Y PATIL ${ }^{2}$ \\ ${ }^{1}$ Department of Pharmacognosy, SVPM's College of Pharmacy, Malegaon (Bk), Baramati, Pune, India. ${ }^{2}$ Department of Pharmacognosy, PDEA's \\ Shankarrao Ursal College of Pharmaceutical Sciences and Research Center, Kharadi, Pune, India. Email: ramdas.kalesvpm@gmail.com
}

Received: 05 August 2020, Revised and Accepted: 10 September 2020

ABSTRACT

Objective: The objective of the study was to evaluate the effect of Piper betle L. leaves extract against clonidine-induced catalepsy and milk-induced leukocytosis and eosinophilia in mice.

Methods: Methanolic extract of $P$. betle L. leaves was prepared using Soxhlet apparatus. Preliminary phytochemical screening of the prepared extract was carried out using standard chemical tests. Effect of the prepared extract was evaluated against clonidine-induced catalepsy and milk-induced leukocytosis and eosinophilia in mice model.

Results: Maximum duration of catalepsy was observed at $90 \mathrm{~min}$ after the clonidine administration. There was a significant inhibition ( $<<0.05)$ of clonidine-induced catalepsy in the animals pretreated with chlorpheniramine maleate and extract of $P$. betle leaves. Administration of milk (4 mg/kg) subcutaneous route exhibited a significant increase in leucocytes and eosinophil count after $24 \mathrm{~h}$ of administration. Methanolic extract of $P$. betle L. leaves showed significant inhibition $(\mathrm{p}<0.05)$ of milk-induced leukocytosis and eosinophilia.

Conclusion: These results suggest that $P$. betle leaves extract may have the potential therapeutic value in the treatment of allergic diseases.

Keywords: Catalepsy, Leukocytosis, Eosinophilia.

(c) 2020 The Authors. Published by Innovare Academic Sciences Pvt Ltd. This is an open access article under the CC BY license (http://creativecommons. org/licenses/by/4. 0/) DOI: http://dx.doi.org/10.22159/ajpcr.2020.v13i11.39321

\section{INTRODUCTION}

Piper betle Linn. is a perennial dioecious climber, stems are semi-woody, much thickened at nodes; leaves large, $15-20 \mathrm{~cm}$ long, broadly ovate, slightly cordate, shortly acuminate, acute, entire, glabrous, yellowish or bright green, shining on both sides [1]. It is commonly known as the betle vine, it is an important medicinal and recreational plant [2]. P. betle is extensively found in damp forests and is propagated in India and other Southeast Asia, such as Vietnam and China [3]. The five main cultivars of P. betle Linn. are Bangla, Desawari, Karpoori, and Sanchi [4]. The betle leaves are nutritive and possess antitumor [5], wound healing [6], antimicrobial [7], antibacterial [8], antioxidant [9], gastroprotective [10], neuroprotective [11], antifilarial [12], antimalarial [13], and analgesic activity [14]. The leaves contain a variety of biologically active components like hydroxychavicol, chavicol, piperbetol, chavibetol, piperol A, methylpiperbetol, and piperol. The key component of the leaf is a volatile oil known as betle oil [15]. Karpoori variety possesses highest content of eugenol [16]. The primary goal of this research was to evaluate the effect of $P$. betle L. leaves extract against clonidine-induced catalepsy and milk-induced leukocytosis and eosinophilia in mice.

\section{MATERIALS AND METHODS}

Collection of plant material

The leaves of $P$. betle were collected from the rural areas of Baramati Dist., Pune (Maharashtra) and identified in the Department of Botany, Agricultural Development Trust's Shardabai Pawar Mahila Mahavidyalaya, Shardanagar Malegaon (Bk), Tal-, Baramati Dist., Pune, Maharashtra, India (Voucher specimen PASR-142).

\section{Drugs and chemicals}

The drugs used were clonidine (Neon Lab. Ltd., India), chlorpheniramine maleate (Pfizer Ltd.), and dexamethasone (Zydus Healthcare Ltd.); all were purchased from a commercial source. Chemical used were methanol (Research Lab. Industries, India).

\section{Extract preparation and phytochemical screening}

The leaves of $P$. betle were dried and crushed to a coarse powder. Powdered material was subjected to Soxhlet extraction with methanol as a solvent. The extract so obtained was concentrated to dryness by evaporating the solvent. The percent yield was calculated. Extract was stored at room temperature and protected from direct sunlight. The prepared extract was subjected to preliminary phytochemical screening using standard chemical tests [17].

\section{Animals}

Swiss albino mice (20-30 g) of either sex were obtained from National Institute of Biosciences, Pune, India. Animals were maintained in our animal house under standard laboratory conditions. Animals were exposed to day-night light cycle and room temperature $\left(24 \pm 2^{\circ} \mathrm{C}\right)$. All animals are allowed free access to readymade food pellets and water. Animals were handled according to standard protocols for the use of laboratory animals [18]. The experimental protocol was approved by the Institutional Animal Ethics Committee (1214/ac/08/CPCSEA).

\section{Acute toxicity study}

Acute toxicity study was performed by oral route in mice as per OECD guidelines 423 .

\section{Clonidine-induced catalepsy in mice}

A bar test was performed to study the effect of clonidine-induced catalepsy [19-21]. Clonidine (1 mg/kg, s.c.) was injected to mice $(\mathrm{n}=6)$. Before $1 \mathrm{~h}$ of clonidine treatment, Group I received dist. water (1 ml/kg i.p.), Group II received chlorpheniramine maleate $(10 \mathrm{mg} / \mathrm{kg}$ body weight, i.p.), Group III received methanolic extract $250 \mathrm{mg} / \mathrm{kg}$ 
body weight i.p. (MEPBL250), and Group IV received methanolic extract $500 \mathrm{mg} / \mathrm{kg}$ body weight i.p.(MEPBL500). The forepaws of mice were placed on a horizontal bar and the time required to remove the paws for each animal was noted and the duration of catalepsy was measured at $15,30,60,90$, and $120 \mathrm{~min}$.

Milk-induced leukocytosis and eosinophilia in mice

Swiss albino mice of either sex weighing between 20 and 30 g were divided into six groups of five animals each. All animals received boiled (boiling temp $70^{\circ} \mathrm{C}$ and boiling time $20 \mathrm{~min}$ ) and cooled milk in dose of $4 \mathrm{ml} / \mathrm{kg}$ subcutaneously. Animals belong to Group I treated as control and received distilled water $10 \mathrm{ml} / \mathrm{kg}$. p.o., Group II received methanolic extract $250 \mathrm{mg} / \mathrm{kg}$.p.o.(MEPBL250), Group III received methanolic extract $500 \mathrm{mg} / \mathrm{kg}$.p.o. (MEPBL500), whereas Group IV received dexamethasone $50 \mathrm{mg} / \mathrm{kg}$ i.p. Extract and standard drug were administered $1 \mathrm{~h}$ before milk injection. Blood samples were collected before and $24 \mathrm{~h}$ after milk administration from the retro-orbital plexus, under light ether anesthesia. Difference in total leukocyte and eosinophil count before and after $24 \mathrm{~h}$ drug administration was calculated [22].

\section{Statistical analysis}

The mean \pm SEM values were calculated for each group. The statistical analysis was performed using one-way analysis of variance (ANOVA) followed by Dunnett's test for individual groups compared with control. $\mathrm{p}<0.05$ was considered as statistically significant.

\section{RESULTS}

\section{Acute toxicity study}

Treatment with methanolic extract up to $2000 \mathrm{mg} / \mathrm{kg}$ orally to mice did not induce mortality. Hence, $\mathrm{LD}_{50}$ was considered to be more than $2000 \mathrm{mg} / \mathrm{kg}$. Based on acute toxicity results, 250 and $500 \mathrm{mg} / \mathrm{kg}$ doses were selected.

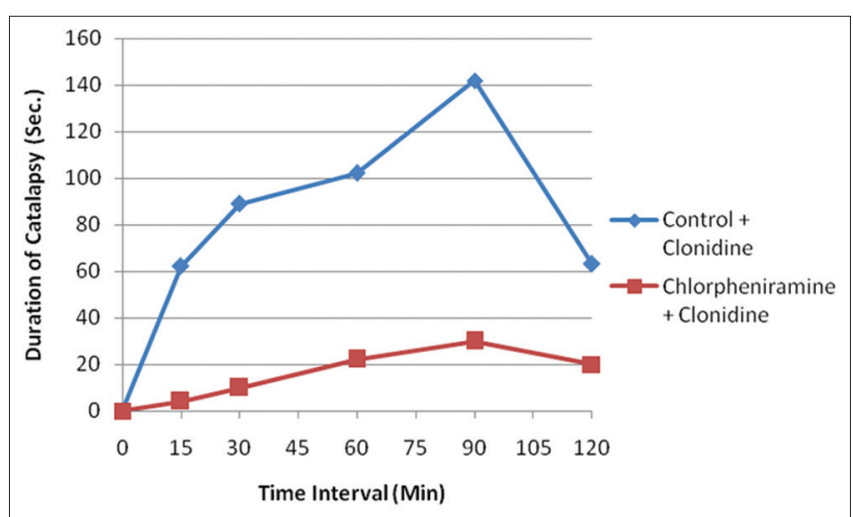

Fig. 1: Effect of chlorpheniramine maleate $(10 \mathrm{mg} / \mathrm{kg}$ body weight, i.p.) on clonidine-induced catalepsy in mice

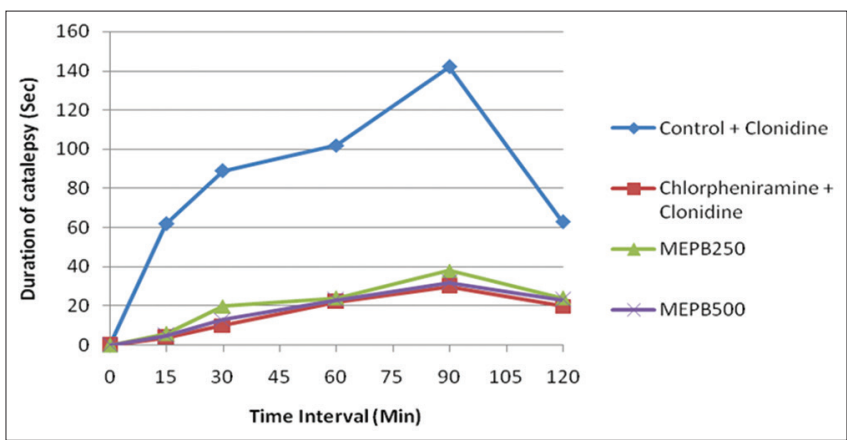

Fig. 2: Effect of Piper betle Linn. leaves extracts on clonidineinduced catalepsy in mice
Preliminary phytochemical screening

Preliminary phytochemical screening of the extract showed the presence of alkaloids, carbohydrates, proteins, flavonoids, phenolic compounds, and tannins.

\section{Clonidine-induced catalepsy}

All the groups showed a maximum duration of catalepsy at $90 \mathrm{~min}$ after the clonidine administration. There was a significant inhibition $(\mathrm{p}<0.05)$ of clonidine-induced catalepsy in the animals pretreated with chlorpheniramine maleate (Fig. 1), MEPBL250, and MEPBL500 (Fig. 2 and Table 1).

Milk-induced leukocytosis and eosinophilia in mice

Subcutaneous administration of boiled and cooled milk at a dose of $4 \mathrm{ml} / \mathrm{kg}$ showed a significant increase in the leukocytes and eosinophils count after $24 \mathrm{~h}$ as compared to leukocyte count before milk administration.

\section{DISCUSSION}

Catalepsy is a condition in which the animal maintains imposed posture for a long time before regaining normal posture. Catalepsy is the sign of the extrapyramidal effect of drugs that inhibit dopaminergic transmission or increase histamine release in the brain. Clonidine, a $\alpha_{2}$-adrenoreceptor agonist induces dose-dependent catalepsy in mice, which is inhibited by $\mathrm{H}_{1}$ receptor antagonist but not by $\mathrm{H}_{2}$ receptor antagonist [23]. It is known that clonidine releases histamine from mast cells [24]. Clonidine-induced release of histamine from mast cells is inhibited by $\alpha_{2}$-adrenoceptor blocker. In the present investigation, all groups showed a maximum duration of catalepsy at $90 \mathrm{~min}$ after the clonidine administration. There was a significant inhibition $(\mathrm{p}<0.05)$ of clonidine-induced catalepsy in the animals pretreated with $P$. betle leaves extract. This indicates the antihistaminic activity of $P$. betle leaves.

During asthmatic inflammation, leukocyte release cytokines, histamine, and major basic protein promote ongoing inflammation. An abnormal

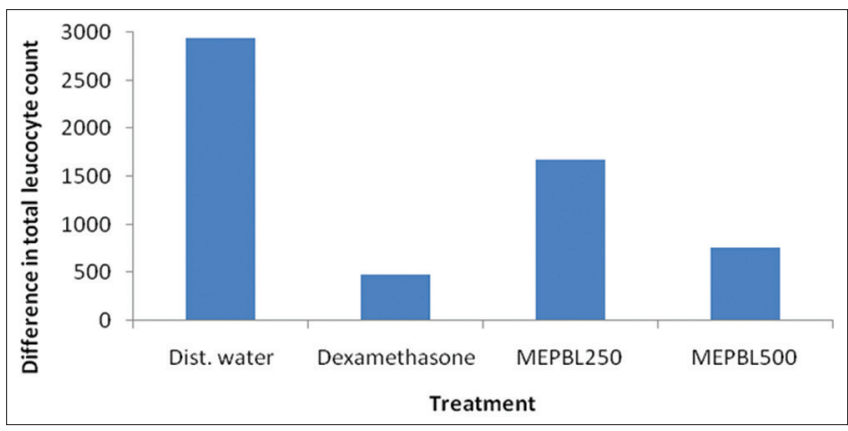

Fig. 3: Effect of Piper betle leaves extract on milk-induced leukocytosis in mice

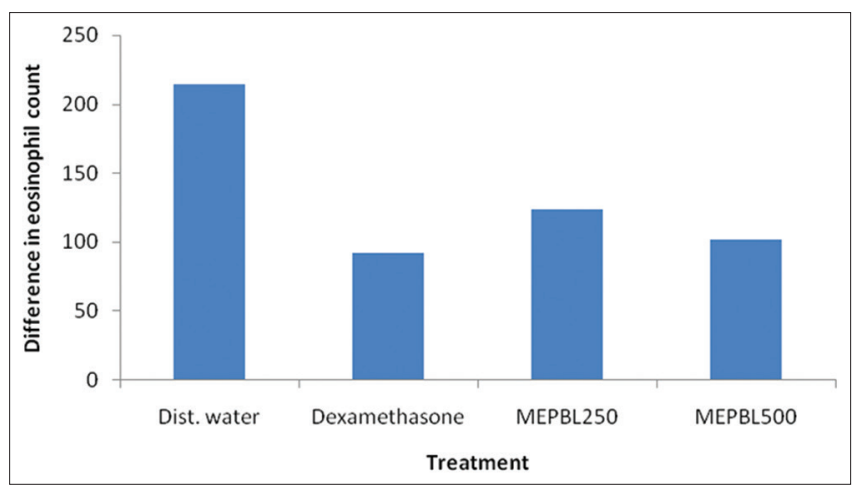

Fig. 4: Effect of Piper betle leaves extract on milk-induced eosinophilia in mice 
Table 1: Effect of Piper betle leaves extracts on clonidine-induced catalepsy in mice

\begin{tabular}{|c|c|c|c|c|c|c|}
\hline \multirow[t]{2}{*}{ S. No. } & \multirow[t]{2}{*}{ Group } & \multicolumn{5}{|c|}{ Duration of catalepsy (sec) at Mean \pm SEM } \\
\hline & & $15 \mathrm{~min}$ & $30 \mathrm{~min}$ & $60 \mathrm{~min}$ & $90 \mathrm{~min}$ & $120 \mathrm{~min}$ \\
\hline 1 & Control & $62.00 \pm 4.46$ & $89.33 \pm 4.82$ & $102.50 \pm 3.81$ & $142.33 \pm 12.38$ & $63.00 \pm 5.19$ \\
\hline 3 & MEPBL 250 & $06.16 \pm 0.94^{*}$ & $19.83 \pm 1.88^{*}$ & $24.00 \pm 2.74^{*}$ & $38.00 \pm 6.19 *$ & $23.66 \pm 2.10^{*}$ \\
\hline 4 & MEPBL 500 & $05.00 \pm 0.73^{*}$ & $13.00 \pm 1.41^{*}$ & $23.00 \pm 2.39 *$ & $32.00 \pm 3.27^{*}$ & $23.50 \pm 4.65^{*}$ \\
\hline
\end{tabular}

Table 2: Effect of Piper betle leaves extract on milk-induced leukocytosis in mice

\begin{tabular}{lll}
\hline Group & Treatment & $\begin{array}{l}\text { Difference in total leukocyte count } \\
\text { (Per cu mm) }(\text { Mean } \pm \text { SEM) }\end{array}$ \\
\hline I & Dist. water & $2936.00 \pm 487.13$ \\
II & MEPBL250 & $1676 \pm 177.83^{*}$ \\
III & MEPBL500 & $760.00 \pm 131.71^{* *}$ \\
VI & Dexamethasone & $476.00 \pm 110.40^{* * *}$ \\
& (50 mg/kg i.p.) \\
\hline \multirow{2}{*}{$\mathrm{p}<0.04,{ }^{* *} \mathrm{p}<0.003,{ }^{* * *} \mathrm{p}<0.001$}
\end{tabular}

Table 3: Effect of Piper betle leaves extract on milk-induced eosinophilia in mice

\begin{tabular}{lll}
\hline Group & Treatment & $\begin{array}{l}\text { Difference total eosinophil count } \\
\text { (per cu mm) (Mean } \pm \text { SEM) }\end{array}$ \\
\hline I & Dist. water & $214.00 \pm 38.64$ \\
II & MEPBL250 & $124.00 \pm 28.57^{*}$ \\
III & MEPBL500 & $102.00 \pm 10.54^{* *}$ \\
VI & Dexamethasone & $92.00 \pm 22.00^{* * *}$ \\
& (50 mg/kg i.p.) & \\
& ${ }^{*} \mathrm{p}<0.098,{ }^{* *} \mathrm{p}<0.023,{ }^{* * *} \mathrm{p}<0.025$ &
\end{tabular}

increase in peripheral eosinophils count more than $4 \%$ of total leukocyte is termed as eosinophilia [25]. After the parental administration of milk, there is an increase in total leukocyte and eosinophil count, this stressful condition can be normalized by the administration of an antistress or adaptogenic drug. The involvement of eosinophil in bronchial mucosa, in which allergic inflammation occurs, is a critical contributor to the late asthmatic reaction of congestion and mucus hypersecretion. In the late phase, especially in the development of allergic asthma, eosinophil plays a role as an inflammatory cell. Eosinophil secrets mediators such as eosinophil cationic protein, tumor necrosis factor, eosinophilderived neurotoxin, and prostaglandin results in epithelial shedding, bronchoconstriction, and promotion of inflammation in the respiratory tract often allergic. In the present study, it has been found that parenteral administration of milk at a dose of $4 \mathrm{ml} / \mathrm{kg}$ significantly induced the total leukocyte and eosinophil count $(\mathrm{p}<0.001)$ after $24 \mathrm{~h}$. Animals of the group treated with MEPBL250 and MEPBL500 significantly inhibited an increase in the number of total leukocyte (Fig. 3 and Table 2) and eosinophil count. (Fig. 4 and Table 3).

\section{CONCLUSION}

The results of the present study revealed that $P$. betle Linn. leaves extract inhibits the clonidine-induced catalepsy and milk-induced leukocytosis and eosinophilia in mice, suggests its potential antihistaminic and antiallergic activities. However, we are screening $P$. betle leaves extract for other animal models of asthma to evaluate its efficacy in the management of asthma. We are also working on a phytochemical investigation of these extracts to pinpoint the chemical constituents responsible for the activity.

\section{ACKNOWLEDGMENTS}

We express our sincere thanks to Management and Principal of SVPM's College of Pharmacy, Malegaon Bk Tal., Baramati Dist., Pune, for providing the necessary research facilities for this study. We also express our gratitude to Prof. R.B. Deshmukh, Head, Dept. of Botany, Agricultural Development Trust's Shardabai Pawar Mahila Mahavidyalaya, Shardanagar Tal-Baramati, for the authentication of the plant.

\section{AUTHORS' CONTRIBUTIONS}

Dr. Ravindra Y. Patil planned and designed the whole work and Ramdas N. Kale did the whole research work.

\section{CONFLICTS OF INTEREST}

The authors confirm that there were no conflicts of interest.

\section{AUTHORS' FUNDING}

This research did not receive any specific grant from funding agencies in the public, commercial, or not-for-profit sectors.

\section{REFERENCES}

1. Warrier PK, Nambier VP, Ramanakutty C. Indian Medicinal Plants. Madras, India: Orient Longman Publishers Ltd.; 1996. p. 279.

2. Kumar N, Misra P, Dube A, Bhattacharya S, Dikshit M, Ranade S. Piper betle Linn. a maligned Pan-Asiatic plant with an array of pharmacological activities and prospects for drug discovery. Curr Sci 2010;99:922-32

3. Bhattacharya S, Banerjee D, Bauri AK, Chattopadhyay S, Bandyopadhyay SK. Healing property of the Piper betel phenol, allylpyrocatechol against indomethacin-induced stomach ulceration and mechanism of action. World J Gastroenterol 2007;13:3705-13.

4. Sapna S, Anju D, Sanju N. Pharmacognostical and phytochemical studies of piper betle Linn leaf. Int J Pharm Pharm Sci 2016;8:222-6.

5. Gundala SR, Aneja R. Piper betel leaf: A reservoir of potential xenohormetic nutraceuticals with cancer-fighting properties. Cancer Prev Res (Phila) 2014;7:477-86.

6. Arif B, Risris K, Tazyinul QA. Wound-healing test of piper betle leaf extract and Aloe vera in gel preparation. Int J Appl Pharm 2018;10:86-91.

7. Marlia S, Sophi D, Natalia P. Antimicrobial activity of standardized piper betel extract and its mouthwash preparation. Int J Pharm Pharm Sci 2014;6:243-6.

8. Agarwal T, Singh R, Shukla AD, Waris I, Gujrati A. Comparative analysis of antibacterial activity of four Piper betel varieties. Adv Appl Sci Res 2012;3:698-705.

9. Jaiswal SG, Patel M, Saxena DK, Naik SN. Antioxidant properties of Piper betel (L) leaf extracts from six different geographical domain of India. J Bioresour Eng Technol 2014;2:12-20.

10. Majumdar B, Chaudhuri SG, Ray A, Bandyopadhyay SK. Effect of ethanol extract of Piper betle Linn leaf on healing of NSAID-induced experimental ulcer--a novel role of free radical scavenging action. Indian J Exp Biol 2003;41:311-5.

11. Chan EW, Wong SK. Phytochemistry and pharmacology of three Piper species: An update. Int J Pharmacogn 2014;1:534-44.

12. Singh M, Shakya S, Soni VK, Dangi A, Kumar N, Bhattacharya SM. The n-hexane and chloroform fractions of Piper betle L. trigger different arms of immune responses in BALB/c mice and exhibit antifilarial activity against human lymphatic filarid Brugia malayi. Int Immunopharmacol 2009;9:716-28.

13. Pal M, Chandrashekar K. Mosquito repellent activity of Piper betel Linn. Int J Pharm Life Sci 2010;1:313-5.

14. Alam B, Akter F, Parvin N, Sharmin Pia R, Akter S, Chowdhury J, et al. Antioxidant, analgesic and anti-inflammatory activities of 
the methanolic extract of Piper betle leaves. Avicenna J Phytomed 2013;3:112-25.

15. Sarma C, Rasane P, Kaur S, Singh J, Singh J, Gat Y, et al. Antioxidant and antimicrobial potential of selected varieties of Piper betle L. (Betel leaf). An Acad Bras Cienc 2018;90:3871-8.

16. Fathima Begam KM, Ravichandran P, Manimekalai V. Phytochemical analysis of some selected varieties of piper betle L. Int J Curr Pharm Res 2018;10:89-93.

17. Khandelwal KR. Practical Pharmacognosy Technique and Experiments. $23^{\text {rd }}$ ed. Pune: Nirali Prakashan; 2005. p. 15-29.

18. National Research Council. Guide for the Care and Use of Laboratory Animals. Washington, DC: Institute for Laboratory Animal Research, National Academics Press; 2011. p. 11-40.

19. Ferré S, Guix T, Prat G, Jane F, Casas M. Is experimental catalepsy properly measured? Pharmacol Biochem Behav 1990;35:753-7.
20. Taur DJ, Nirmal SA, Patil RY. Effect of various extracts of Ficus bengalensis bark on clonidine and haloperidol-induced catalepsy in mice. Pharmacologyonline 2007;3:470-7.

21. Ghaisas MM, Bulani VD, Suralkar AA, Limaye RP. Effect of Calotropis gigantea on clonidine and haloperidol induced catalepsy. Pharmacologyonline 2009;3:484-8

22. Bhargava KP, Singh N. Anti-stress activity of Ocimum sanctum Linn. Indian J Med Res 1981;73:443-51.

23. Jadhav JH, Balsara JJ, Chandorkar AG. Involvement of histaminergic mechanisms in the cataleptogenic effect of clonidine in mice. J Pharm Pharmacol 1983;35:671-3

24. Lakdawala AD, Dadkar NK, Dohadwalla AN. Action of clonidine on the mast cells of rats. J Pharm Pharmacol 1980;32:790-1.

25. Brekhman LI, Dardymov IV. New substances of plant origin which increase nonspecific resistance. Annu Rev Pharmacol 1969;9:419-28. 